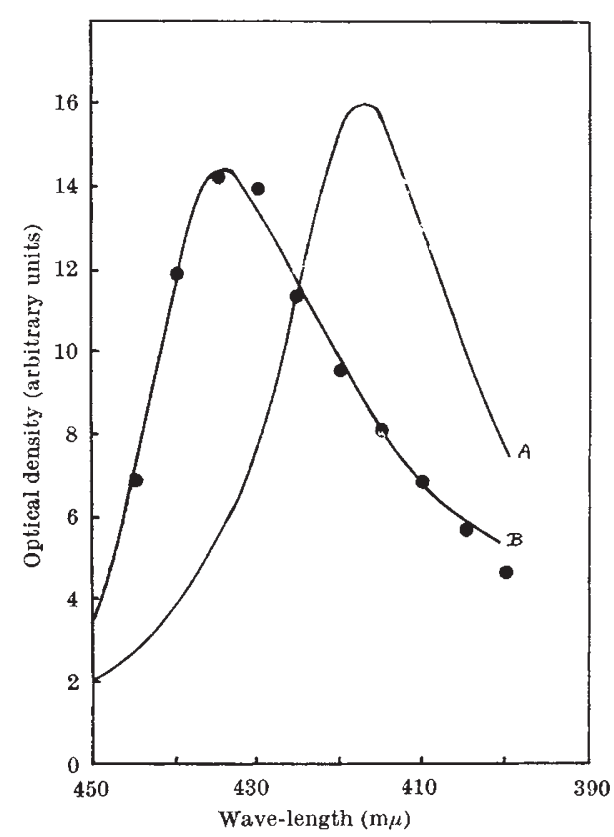

Fig. 1. The continuous lines show the absorption spectra for solutions of reduced myoglobin and oxymyoglobin determined with a spectrophotometer. The points represent the spectrum of the product of flash photolysis of oxymy

flash photolysis may become a useful tool in studies of enzyme action.

We are indebted to the Medical Research Council for grants in aid of this work.

Department of Biochemistry, University of Sheffield.

${ }^{1}$ Haldane, J. S., and Lorrain Smith, J., J. Physiol., 20, 497 (1896). 2 Keilin, D., and Hartree, L. F., Biochem. J., 61, 153 (1955).

s Norrish, R. G. W., and Porter, G., Disc. Farad. Soc., 17, 40 (1954). + Gibson, Q. H., J. Physiol., 134, 112 (1956).

\section{5-Hydroxytryptamine and Anaphylactic Shock}

IT is generally accepted that histamine plays an important part in anaphylactic shock. In recent years, attention has been directed to 5-hydroxytryptamine, since this substance, together with histamine, is liberated from the platelets by the antigen-antibody reaction ${ }^{1}$. Further, 5-hydroxytryptamine causes a shock syndrome in guinea pigs which is similar to that caused by anaphylaxis'. Although Herxheimer was unable to protect guinea pigs from anaphylactic shock using lysergic acid diethylamide, a potent and specific antagonist of 5-hydroxytryptamine, Pallotta and Ward $^{3}$ have observed significant protection using intravenous doses of lysergic acid diethylamide.

We have now attemptod to determine, using the Dale-Schultz reaction, whether the substance responsible for the contraction of the sensitized guinea pig and rat uteri in the presence of antigen is histamine or 5-hydroxytryptamine. It was found that the guinea pig uteri (whether from sensitized or normal animals) are at least 1,000 times more sensitive to histamine than they are to 5-hydroxytryptamine, the threshold concentration of histamine being $10^{-8} \mathrm{gm}$./ ml. Guinea pigs were sensitized to horse serum and used for the Dale-Schultz reaction 3-4 weeks later.
Table 1. The Sensitivity of The Guinea PIA AND Rat UTERI To Histamine AND 5-HYDROXYTRY PTAMINE (5-HT), AND THE EFFECT OF ANTagonists on the Dale-Schultz REACTion in those SPECiES

\begin{tabular}{|c|c|c|c|c|}
\hline \multirow[b]{2}{*}{ Species } & \multicolumn{2}{|c|}{$\begin{array}{l}\text { Sensitivity } \\
\text { of uterus }\end{array}$} & \multicolumn{2}{|c|}{$\begin{array}{c}\text { Prevention of } \\
\text { Dale-Schultz reaction }\end{array}$} \\
\hline & $\begin{array}{c}\text { Hiatamine } \\
+ \\
0\end{array}$ & $\begin{array}{c}5-\mathrm{HT} \\
0 \\
+\end{array}$ & $\begin{array}{c}\text { Mepyramine } \\
+ \\
0\end{array}$ & $\begin{array}{c}\mathrm{BOL}_{2} 148^{\prime} \\
0 \\
+\end{array}$ \\
\hline
\end{tabular}

One half of the horn of the uterus of such animals was set up in the organ bath and shown to contract maximally to the first addition of the specific antigen. The reaction of the other half of the horn to the antigen was then tested in the presence of either mepyramine $\left(10^{-6} \mathrm{gm} . / \mathrm{ml}.\right)$ or the bromo derivative of lysergic acid diethylamide, 'BOL $148^{\prime}\left(10^{-5} \mathrm{gm} . /\right.$ ml.). In each of the four tests, mepyramine blocked the reaction, but ' $\mathrm{BOL}$ 148' when tested similarly was without effect.

When similar experiments were performed with rat uteri, however, a completely different result was obtained (see Table 1). Uteri of rats (whether from sensitized or normal animals) are at least 1,000 times more sensitive to 5-hydroxytryptamine than they are to histamine, the threshold concentration of the former being $10^{-8} \mathrm{gm} . / \mathrm{ml}$. Rats were sensitized by one intraperitoneal injection of either fresh eggwhite alone ( $2 \mathrm{ml} .50$ per cent solution) or horse serum (1 ml.) with Hoemophilus pertussis vaccine $\left(20,000 \times 10^{-6}\right.$ organisms, phase I), and used for the Dale-Schultz reaction 12-20 days later. One horn of the uterus of such animals was set up in the organ bath and shown to contract on the first addition of the specific antigen. The reaction of the other horn to the antigen was then tested in the presence of either 'BOL 148' (10-6 $\mathrm{gm}$. .) $\mathrm{ml}$.) or mepyramine $\left(10^{-5} \mathrm{gm} . / \mathrm{ml}\right.$.). In each of four tests, 'BOL 148' completely blocked the reaction but mepyramine was without effect when tested similarly, as was also atropine $\left(10^{-7} \mathrm{gm} . / \mathrm{ml}\right.$.).

These results illustrate an important species difference in the anaphylactic reaction of the isolated actively sensitized uterus. It appears that, in such a reaction, histamine plays a major part in the guinea pig, whereas in the rat (as in the mouse ${ }^{4}$ ) 5-hydroxytryptamine plays a more important part than histamine. However, Brocklehurst ${ }^{5}$ has recently noted that lysergic acid diethylamide did not antagonize the Dale-Schultz reaction in a passively sensitized rat. Further experiments are now in progress to determine the role of 5-hydroxytryptamine in the general anaphylactic reaction in various species.

\section{R. K. SANYAL}

G. B. West

Dapt. of Pharmacology,

School of Pharmacy,

17 Bloomsbury Square, London, W.C.1.

${ }^{1}$ Humphrey and Jaques, J. Physiol., 128, 9 (1955).

${ }^{2}$ Herxheimer, J. Physiol., 1\&8, 435 (1955).

${ }^{3}$ Pallotta and Ward, J. Pharmxcol., 119, 174 (1957).

${ }^{4}$ Hink, Proc. Soc. Exp. Biol., 92, 673 (1958).

${ }^{5}$ Brocklehurst, Symposium on 5-Hydruxytryptamine, London, April 1-2, 1957.

\section{Inhibition of Ascorbic Acid Oxidase by Thiourea}

Although ascorbic acid oxidase is regarded as a copper enzyme, thiourea has not been reported as an inhibitor of it. Previous reports, in fact, point out a lack of inhibition of the oxidase by thiourea $a^{1,2}$, although phenol thiourea has bean stated to be inhibitor ${ }^{3,4}$. During a study of the ascorbic acid 